\title{
Increased Product Sales Value Through Promotion, Innovation, and Utilization of Information Technology
}

\author{
Sukirman', Arwani' $^{2}$, M. Zazuli ${ }^{3}$ \\ \{sukirman@umk.ac.id ${ }^{1}$ \} \\ Master of the management study program at the Faculty of Economics and Business, Muria Kudus University, \\ Central Java, Indonesia. ${ }^{12}$ Information Engineering Study Program Faculty of Engineering, Muria Kudus \\ University, Central Java, Indonesia. ${ }^{3}$
}

\begin{abstract}
This study aims to analyze the effect of promotion, product innovation, and the use of information technology on product sales value on the efforts of Muria Kudus University students. The variables used in this study consisted of three independent variables and one dependent variable. Promotion, Product Innovation, and Utilization of Information Technology are independent variables and Product Selling Value is the dependent variable. This study uses a survey method for students of the Muria Kudus University Entrepreneurship development program. The population in this study were students who took the compulsory entrepreneurial skills of Muria Kudus University as many as 846 people. The sample of 79 respondents, data analysis using SPSS (Statistical Product and Services Solutions). The test results show that the use of IT has the most powerful and significant influence on increasing the selling value of the business products of Muria Kudus University students. Product innovation has the weakest influence on increasing the sale value of the product. The promotion also influences the selling value of student business products. Promotion, product innovation and the use of IT together have a significant influence on increasing the sale value of products.
\end{abstract}

Keywords: promotion, product innovation, IT utilization, selling value increase.

\section{Introduction}

Increasing business productivity is needed for business empowerment aimed at developing sciencebased and globally competitive businesses. The strategy of empowering small businesses is directed at building innovation and technology competencies so that they play a greater role in developing economic growth. Student business growth is not in line with expectations, so it is necessary to increase the sale value of products to encourage economic growth through student entrepreneurship in developing entrepreneurial knowledge towards the global market.

Stated that common problems faced by entrepreneurs in Indonesia in developing their businesses include: limited funding for business development; lack of information and access to raw materials and markets; low quality of human resources; low ability to produce innovative products; and weak incubation assistance[1].

This research is expected to be able to increase the selling value of student business products at the Muria Kudus University by raising the regional superior potential and creative industries to achieve global competition. In 2018 Muria Kudus University had 82 student business units with a workforce of around 206 people. Whereas in 2019 there was a change in the number of business units to 86 business units with a total workforce of 236 people. Based on sales data on campus, there are approximately $86 \%$ of student business products sold, including in the form of convection, headscarves, robes, 
wedding equipment and also in the form of foods such as chicken geprek, coffee saturation point, gahya dahar, kebab and travel agency services.

The establishment of an increase in student business productivity is more based on the desire of students who can create innovation, especially in 201923 groups of student business units that have made product innovation development. Also supported by an increase in student business promotion through trade shows, online marketing, utilizing information technology through facebooks, instagram, time-ups, and so on to develop markets. This condition is hampered by the ability of students who are still weak in the face of competition, so it is necessary to form an increase in the selling value of student business products so that it becomes stronger, also encouraged by the existence of a co-19 pandemic that impedes marketing, so it cannot directly make sales. Therefore it is necessary to increase the selling value of student business products through promotion, product innovation, and the use of information technology.

\section{Literature Review}

Someone who carries out business activities, or starts and operates a business is said to be an entrepreneur [2]. Entrepreneurs are the pillars of a country's economic support, therefore it can be said that entrepreneurship is the ability of a person to make an effort to face life's challenges. Entrepreneurs are considered successful if they have 10 categories, including commitment and unlimited determination, a strong drive to achieve achievement, orientation towards opportunities, internal control, tolerance for ambiguity, skills in accepting risk, a less perceived need for status and power, ability to solve problems, ability get "feedback" (feedback), and the ability to deal with failure[3]. Entrepreneurship training does not merely provide a theoretical foundation but forms the attitude, behavior, and mindset of an entrepreneur[4]. Entrepreneurship is to change the views, attitudes, and interests of students to understand entrepreneurship, and to have reasoning power about entrepreneurship so that it is expected to become a new entrepreneur and be able to open new job opportunities

Entrepreneurship training depends on the acceptance of the entrepreneurial mindset at the university and the creation of an entrepreneurial environment in and around the University. Therefore, entrepreneurship courses need to be specially designed to be able to develop entrepreneurial characteristics, such as creativity, decision making, leadership, social networking, time management, teamwork, and others. Therefore, it is necessary to increase the selling value of student business products through promotion, product innovation, and the use of information technology.

\subsection{The effect of promotion on increasing the sale value of products}

The promotion has a positive and significant effect on increasing product sales value. Promotion is all activities intended to convey or communicate a product to the target market, to provide information about features, uses and most importantly is about its existence, to change attitudes or to encourage people to act in buying a product[6]. Promotion is a company's effort to influence "actual consumers" and "potential customers" so that they want to make a purchase of the products offered, now or in the future[7]. Actual consumers are consumers who directly buy the products offered at or immediately after the product promotion is launched by the company, and potential consumers are consumers who are interested in making purchases of products offered by the company in the future.

In addition to being able to encourage consumers to buy products, it is also expected to be able to create prospective new buyers[5]. The attitude and mentality of consumers can be formed because of the promotion. In general, promotion is part of the sales process by applying the principles and methods 
to the formation of new buyers to consumers through an integrated approach developed by businesses. Promotion is essentially a marketing communication, meaning marketing activities that seek to disseminate information, influence, persuade, or remind the target market for companies and their products to be willing to accept, buy and be loyal to the products offered company concerned[8]. Promotion can improve the attitude of the formation of consumers to buy from products offered by businesses[9]. Entrepreneurship can be learned and trained by every individual who has a desire because entrepreneurship is not the dominance of talented individuals[10]. On this basis, the development of the proposed hypothesis is as follows:

H1: The more often the promotion is carried out, it will influence the increase in the selling value of the student business products of the Entrepreneurship Obligatory Skills Program of Muira Kudus University.

\subsection{Effect of Innovation on Increasing Product Sales Value}

Innovation can also be expressed as an embodiment, combination, or synthesis of original, relevant knowledge, new value products, a process, or service. Innovation usually involves creativity, but the two are not identical. Innovation involves creative actions or ideas to make some specific and real differences in the domain where innovation is made. Innovation also includes the transformation of new products, which can be processed also in the form of services to meet the needs of customers. Innovation also includes technical, physical, and knowledge processes that aim primarily to develop products. Whereas innovation is beneficial in companies for creating new value propositions through a series of activities such as offering new products or services, adopting new organizational and operational practices, providing solutions to technology or creating new skills and competencies, innovation can also foster the skills and knowledge needed to effectively realize, mastering and improving existing technologies, and to create something new[11].

Innovation is the process of creating a commercial product from an invention. The most characteristic benefits of an innovation are providing knowledge, building a brand, building a new container in the form of a new community, and creating a new culture. The reason some companies do innovation is innovation makes a profit for the company, innovation that produces a product or service at a low cost or innovation that gives differentiation to the product so that it gives more price for the additional cost of differentiation. Successful innovation occurs when a product is received and produces profits for the company. Whereas the innovation process can be seen when a series of adoption of an existing thing is then differentiated to create a newer thing that has more value and benefits [12].

Innovation helps businesses to develop the products needed to provide information for their users [13]. A business organization is expected to be able to create innovation to carry out the desired development. The ability to create innovation in developing products is very much needed for business people so that they can build an increase in product sales in the future for the sake of smooth business[14]. The expansion of innovation is a major factor in creating ideas, to create satisfaction for customers, which has an impact on increasing the value of selling greater products. On this basis, the research hypothesis can be developed as follows.

H2: The higher the innovation created, the higher the increase in product sales value for students of the Muria Kudus University Compulsory Entrepreneurship Skills Program.

\subsection{The influence of IT utilization on the Product Selling value}

There are still students who have businesses that do not understand the use of IT in running a business, due to the lack of knowledge of the IT software used. The desire of entrepreneurship has attracted many students, therefore at the Muria Kudus University, the Obligatory Entrepreneurship 
Skills Program already has an entrepreneurial community called Young Muria Entrepreneurs. the use of IT can provide increased product sales value[15]. IT is an information system about how users come to receive and utilize technology[16].

Entrepreneurship is the ability to create something new and different[17]. The use of information technology directly affects sales[18]. The relationship between IT utilization and sales lies in the process of utilizing technology by using software that can help work faster, shorter, and simplify work for businesses, to create a variety of designs and models that result in an interest in developing the business becomes stronger. Found a positive and significant relationship between the sophistication of information technology with product sales[19]. The use of IT hurts the product sale value[20]. On this basis, the following hypotheses are developed:

H3: The higher level of IT utilization will affect increasing the sale value of student business products at the Muria Kudus University Entrepreneurship Development Program

\subsection{The Effect of Promotion, Innovation, and Utilization of IT Together on Increasing Product Sales Value}

Product innovation shows the development and introduction of new or developed products that are successful in marketing[21]. Product innovation can be in the form of changes in product design, components, and architecture. Product innovation is a potential thing to creative thinking and imagination of people who ultimately create customers[22]. Product innovation is an important way for companies to remain able to adapt to markets, technology, and competition[23]. There are two conceptions of innovation, 1) innovation, and 2) the capacity to innovate[24]. Ginanjar Suendro's Innovation 235 Journal of Marketing Science Indonesia is a mind about openness to new ideas as a corporate culture. While the capacity to innovate is the company's ability to use or apply new ideas, processes, or products successfully. Based on the limitations of this study that discusses the innovation of new products, the conception of innovation that is appropriate to use is the capacity to innovate, more specifically on technical innovation. Technical innovation has a strong and positive influence on market performance [24]. Likewise, other studies have shown that to gain competitive advantage, market performance is influenced by market orientation, learning orientation, and innovation. Innovation can also act as an intervening variable of market orientation and learning orientation towards company performance[25].

Based on data from the Emarketer digital marketing research institute in 2018 the influence of information technology especially social media is very helpful in this promotion activity because of the 100 million people who are active smartphone users in Indonesia. The application of entrepreneurship courses at Muria Kudus University produces many students and alumni who have businesses and they do promotions by utilizing information technology, namely social media. The purpose of this study was to determine the effect of information technology-based innovation and promotion on increasing product sales value. This shows that in promoting online four variables play an important role, in other words, must pay attention to Content, Trust, Price, and Product in every IT-based promotion. These four variables are interrelated with one another in sustaining IT-based promotion where young entrepreneurs must balance these four variables. These four variables cannot stand alone in conducting IT-based promotions.

On this basis, the development of hypotheses is proposed as follows:

H4: Promotion, innovation, and the use of IT together can increase the selling value of the products of the business products of the Muria Kudus University Entrepreneurship Development Program. 


\section{Method}

\subsection{Research Samples and Data}

The study used a population of undergraduate students in the Entrepreneurship Obligatory Skills Program in 2019/2020 Muria Kudus University as many as 846 students. Sampling uses a convenience sampling method, which is to provide a questionnaire to respondents who are already small business operators and who are interested in becoming entrepreneurs. The sampling technique using a purposive sampling method. The purposive sampling method is a sampling technique with consideration of certain criteria [26]. The purposive sampling method usually uses certain criteria. The sample criteria in this study are:

Table 1 .The sample selection process is based on criteria

\begin{tabular}{cll}
\hline \multicolumn{4}{c}{ Kriteria } & Jumlah \\
\hline No. & Already have your own business & 21 \\
2. & Continuing the efforts of parents & $\mathbf{1 9}$ \\
3. & Very interested in becoming an entrepreneur & $\mathbf{3 0}$ \\
4 & Collaborate with friends or have an internship & $\mathbf{9}$ \\
\hline & Number of Samples & $\mathbf{7 9}$ \\
\hline
\end{tabular}

The analytical method used in this study is a quantitative analysis method. Quantitative analysis uses numbers, statistical calculations to analyze hypotheses and several other analytical tools. Quantitative data analysis using SPSS (Statistical Package for Social Science) software. Analysis of the data used in this study is logistic regression analysis. This logistic regression analysis aims to find out the equation of the regression model of the influence of promotional conditions, product innovation and the use of IT to the product sale value.

\section{Results And Discussion}

\subsection{Classic assumption test}

\subsection{Multicollinearity Test}

Multicollinearity test is done by looking at the tolerance value or VIF value with the assumption that if the tolerance value is $>0.1$ and the VIF value $<10$ then there is no symptom of multicollinearity[27]. Based on the SPSS calculation results, the multicollinearity test is obtained as follows:

Table 2.Multicollinearity Test Results

\begin{tabular}{clll}
\hline Variabel & Tolerance & VIF & Keterangan \\
\hline Promotion $\left(\mathrm{X}_{1}\right)$ & 0,291 & 3,434 & Multicollinearity free \\
Inovation $\left(\mathrm{X}_{2}\right)$ & 0,242 & 4,135 & Multicollinearity free \\
Utilization of IT $\left(\mathrm{X}_{3}\right)$ & 0,318 & 3,148 & Multicollinearity free \\
\hline
\end{tabular}

Primary data source processed. 
From table 2., the multicollinearity test shows that there is no tolerance value greater than 0.1 and a VIF value less than 10.0 so that it can be concluded that there is no multicollinearity for the equation model used.

\subsection{Heteroscedasticity Test}

Testing heteroscedasticity in this study using the Glejser test that is by comparing the absolute value of residuals with independent variables. If the probability value (sig value) of the independent variable $>0.05$ then there is no heteroscedasticity. Heteroscedasticity test results with the help of the SPSS program computer are shown in table 3 as follows:

\begin{tabular}{llllll}
\multicolumn{5}{c}{ Table 3.Heteroscedasticity Test Results Coefficients } \\
\hline & \multicolumn{2}{l}{$\begin{array}{l}\text { Unstandardized } \\
\text { Coefficients }\end{array}$} & $\begin{array}{l}\text { Standardized } \\
\text { Coefficients }\end{array}$ & T & Sig. \\
& B & Std. Error & Beta & & \\
\hline (Constant) & 2,105 &, 839 & & 2,510 &, 014 \\
Promosi (X1) &,- 018 &, 066 &,- 056 &,- 268 &, 789 \\
Inovasi (X2) &,- 157 &, 126 &,- 287 & $-1,247$ &, 216 \\
Pemanfaatan TI (X3) &, 076 &, 074 &, 206 & 1,029 &, 307 \\
a. Dependent Variable: AbsRes & & & & & \\
\hline
\end{tabular}

Source: Results of analysis of processed data, 2020.

From table 3 Heteroscedasticity test shows that there is no sig value of independent variable smaller than 0.05 so it can be concluded that there is no heteroscedasticity for the equation model used.

\subsection{Normality Test}

To determine the normality used the Kolmogorov-Smirnov Test One Sample technique. The results of the normality test are presented in table 4.

Table 4.One Sample Kolmogorof-Smirnov Test Result One-Sample Kolmogorov-Smirnov Test

\begin{tabular}{lll}
\hline & & $\begin{array}{l}\text { Unstandardized } \\
\text { Residual }\end{array}$ \\
& & 79 \\
$\mathrm{~N}$ & & $0 \mathrm{E}-7$ \\
Normal & $0 \mathrm{E}-7$ & 1,78830842 \\
Parameters ${ }^{\mathrm{a}, \mathrm{b}}$ & 1,36768772 & 0,132 \\
&, 106 & 0,109 \\
Most Extreme &, 106 & $-0,132$ \\
Differences & &, 093 \\
\multicolumn{2}{l}{ Kolmogorov-Smirnov Z } &, 336 \\
\multicolumn{2}{l}{ Asymp. Sig. (2-tailed) } & \\
\hline
\end{tabular}

a. Test distribution is Normal.

b. Calculated from data.

Sumber: data awal diolah, 2020 
The data normality test results with the Kolmogorov-Smirnov One-Sample Test above show the Asymp value. Sig (2-tailed) of $0.336>0.05$ so that said residual data are normally distributed, normality requirements are met.

\subsection{Regression Analysis}

This analysis is used to calculate the magnitude of the influence between promotion variables, product innovation and IT utilization on the increase in product sales value can be seen through the regression equation in table 5 .

Table 5.Regression Analysis Results

\begin{tabular}{|c|c|c|c|c|c|c|}
\hline & \multirow{3}{*}{ Model } & \multicolumn{5}{|c|}{ Coefficients $^{\mathrm{a}}$} \\
\hline & & \multicolumn{2}{|c|}{$\begin{array}{c}\text { Unstandardized } \\
\text { Coefficients }\end{array}$} & \multirow{2}{*}{$\begin{array}{c}\text { Standardized } \\
\text { Coefficients } \\
\text { Beta }\end{array}$} & \multirow[t]{2}{*}{$\mathrm{t}$} & \multirow[t]{2}{*}{ Sig. } \\
\hline & & $\mathrm{B}$ & Std. Error & & & \\
\hline \multirow{4}{*}{1} & (Constant) & 2,553 & 1,223 & & 2,088 & 0,040 \\
\hline & Promosi (X1) & 0,277 & 0,096 & 0,289 & 2,892 & 0,005 \\
\hline & Inovasi (X2) & 0,492 & 0,184 & 0,294 & 2,680 & 0,009 \\
\hline & Pemanfaatan TI (X3) & 0,410 & 0,107 & 0,366 & 3,821 & 0,000 \\
\hline
\end{tabular}

a. Dependent Variable: Product Selling Value (Y)

Source: Primary data processed, 2020.

The results of the calculation of the regression analysis are formulated into the following equation:

$\mathrm{Y}=2,553+0,277 \mathrm{X} 1+0,492 \mathrm{X} 2+0,410 \mathrm{X} 3+\mathrm{e}$

a. A value of 2.553 is a constant value, meaning that without any influence from the three independent variables,

the product selling value variable $(\mathrm{Y})$ has a value of that constant that is 2.553 .

b. The regression coefficient of 0.277 states that every promotion increases by one unit will increase the selling

value of the product by 0.277 without being influenced by other variables.

c. Regression coefficient 0.492 states that every promotion increases by one unit will increase the selling value

of products by 0.492 without being influenced by other variables.

d. Regression coefficient 0.410 states that every increase in IT utilization by one unit will increase the product

sales value by 0.410 without being influenced by other variables.

\subsection{Partial Hypothesis Test (t-Test)}

The t-test shows how far the influence of one independent variable individually in explaining the variation of the dependent variable with the assumption that the other variables are constant. Based on the test results, the following results are obtained.

Table 6.Partial Analysis Results (significance $\alpha=0.5 \%$ one-sided test)

\begin{tabular}{|c|c|c|c|c|c|}
\hline Variabel & \multicolumn{2}{|c|}{$\mathrm{t}$ hitung : $\mathrm{t}$ tabel } & \multicolumn{2}{|l|}{ Prob Sig } & \multirow[t]{2}{*}{ Keterangan } \\
\hline & $\mathrm{t}$ hitung & $\mathrm{t}$ tabel & Sig & $\alpha=0,5 \%$ & \\
\hline Promosi (X1) & 2,892 & 1,665 & 0,005 & 0,05 & Signifikan \\
\hline
\end{tabular}




\begin{tabular}{lccccc}
\hline Inovasi (X2) & 2,680 & 1,665 & 0,009 & 0,05 & Signifikan \\
Pemanfaatan TI (X3) & 3,821 & 1,665 & 0,000 & 0,05 & Signifikan \\
\hline
\end{tabular}

1. Hypothesis 1 Testing:

$=0.05$, so we get a degree of freedom $(\mathrm{df}=\mathrm{n}-\mathrm{k}-1)$ Determining one-sided test with samples 116 and $\mathrm{df}=116-3-1=112$, then the table $=\mathrm{t} 0.05 ; 75=1.665$. Account value of $2.892>$ table of 1.665 and probability value of $0.005<0.05$, meaning that the promotion variable affects on and significant in increasing the sale value of the product.

2. Hypothesis 2 Testing:

Account value of $2.680>$ table of 1.665 and probability value of $0.009<0.05$, the innovation variables have a significant and significant effect on increasing the sale value of the product.

3. Hypothesis 3 Testing:

Account value of $3,821>$ table of 1,665 and probability value of $0,000<0.05$, meaning that the utilization of IT variables has an effect on and significantly increases the selling price of the product.

4. Multiple Regression (Test F)

Multiple regression analysis is carried out based on the assumption that all independent variables consisting of promotion, innovation, and multiple IT use affect increasing product sales value.

Tabel 7.Multiple Testing Results (Signifikansi $\alpha=5 \%$ ) ANOVAa

\begin{tabular}{llllll}
\hline Model & Sum of Squares & Df & Mean Square & F & Sig. \\
\hline Regression & 521,083 & 3 & 173,694 & 89,285 &, $000^{\mathrm{b}}$ \\
Residual & 145,904 & 75 & 1,945 & & \\
Total & 666,987 & 78 & & & \\
\hline
\end{tabular}

a. Dependent Variable: product selling value (Y)

b. Predictors: (Constant), IT utilization (X3), promotion (X1), innovation (X2)

Source: Results of processed data analysis (2020).

Account value of $89.285>\mathrm{Ft} 2.77$ and a probability value of $0.000<0.05$ this means that the promotion, innovation, and IT utilization variables have a significant influence together to increase the sale value of the product.

\subsection{Adjusted R Square}

Adjusted R Square test is used to see how much influence the variables outside of the regression model (confounding variables) affect the increase in product sales value, can be seen in table 8

Tabel 8. Nilai Adjusted R Square Model Summary

\begin{tabular}{ccccc}
\hline Model & & & & \\
& $\mathrm{R}$ & $\mathrm{R}$ Square & Adjusted R Square & Std. Error of the Estimate \\
\hline 1 & $0,884^{\mathrm{a}}$ & 0,781 & 0,772 & 1,395 \\
\hline \multicolumn{4}{c}{ a. Predictors: (Constant), Utilization of IT (X3), Promotion (X1), Innovation (X2) } \\
\multicolumn{4}{r}{ Source: Results of processed data analysis (2020). }
\end{tabular}

Based on the calculation, the adjusted $\mathrm{R}$ square value of 0.772 means that the independent variable which consists of promotion, innovation, and utilization of IT contributes $77.2 \%$ to the increase in product sales value in small businesses of UMK students, so there are independent variables outside this regression model that affect the increase in product sales value at UMK student businesses by 
22.8\%. DISCUSSION Effect of Promotion Against Increased Product Sales Value The results showed that promotion had an influence and a significant effect on increasing the sale value of products in small businesses of UMK students. The results of the regression coefficient, the promotion variable (X1) influences on increasing the selling value of products by 0.277 . This condition shows that every promotion increases by 1 unit, it can increase the selling value of products by 0.277 without being influenced by other variables. The higher the level of promotion is run, it will further increase the selling value of products at UMK student businesses. Social media has several advantages that make it stronger than traditional media: (1) Accessibility Social media is easy to access because it requires little or no cost in its use. (2) Speed, content created in social media is available to all people in the network, forums, or communities as soon as it is published. (3). Interactivity, social media can accommodate two or more communication channels. (4). Longevity / Volatility, content on social media can be accessed for a long time, or even forever. (5) Reach, the Internet offers unlimited coverage to all available content[28]. If consumers have started to be interested in a product, it will try to buy and can be a beautiful connector to other consumers if the product is felt according to their wishes. Conversely, this promotion will not be effective if consumers feel incompatible with the product they bought, the consequences can be an obstacle in increasing sales[29][30]. The results of this study that promotion had a significant effect on increasing product sales value.

\subsection{Influence of Innovation on Increasing Product Sales Value}

The results showed that innovation had a significant and significant effect on increasing the selling value of UMK student business products. The results of the regression coefficient, the innovation variable (X2) influences on increasing the selling value of products by 0.492 . This condition shows that every time there is an increase in product innovation by 1 unit, it will increase the product sales value by 0.492 without being influenced by other variables. The higher level of innovation carried out with a product will increase the selling value of the product at UMK student businesses. This research supports the theory which shows that the higher the product innovation that is carried out by the company will improve the company's performance through increasing purchasing decisions[31]. In global competition, companies must be able to modify their products to add value to the products they produce and must be able to meet the needs and tastes of consumers. The added value of the products produced can be in the form of designs / models of products produced and services of products sold[32]. This result is a significant influence between product innovation on increasing the sale value of the product.

\subsection{The Effect of IT Utilization on Increasing Product Sales Value}

The results showed that the use of IT had a positive and significant effect on increasing the sale value of products at UMK student businesses. The results of the regression coefficient, the variable utilization of IT (X3) influences on increasing product sales value of 0.410 . This condition shows that every time there is an increase in the use of IT by 1 unit it will increase the product sales value by 0.410 without being influenced by other variables. The higher the level of IT utilization that is carried out will increase the selling value of UMK student business products. This research supports the theory of innovation, which states that innovation is the core of product changes expected by consumers. Lack of communication in creating products is often caused by external relations between producers and consumers. To form a good cooperative relationship, it is necessary to build a relationship between all components in the company, with users, especially in the relationship between producers and consumers both formally and informally in creating products. 


\section{Conclusion}

Based on the results of research and hypothesis testing, the following conclusions can be drawn:

1. Promotion is proven to have a significant effect on increasing the sale value of products in the efforts of Muria Kudus University students.

2. Product innovation is proven to have a significant effect on increasing the sale value of products in the efforts of Muria Kudus University students.

3. The utilization of IT has been proven to have a significant influence on increasing the sale value of products in the efforts of Muria Kudus University students.

4. Promotion, product innovation, and the use of IT together have a significant effect on increasing the selling value of the business products of Muria Kudus University students.

5. The product innovation variable is the weakest effect on increasing the sale value of the product while the IT utilization variable is the strongest influence on increasing the selling value of the business products of Muria Kudus University students.

Based on the results of hypothesis testing, the suggestions given are as follows:

1. Innovation has the weakest influence on increasing product sales value in the efforts of Muria Kudus University students, so businesses need to improve product development ideas in the face of competition to be able to become winners and consumers increasingly hunt for the products they create.

2. Utilization of IT has the most powerful influence on increasing the sale value of products at the Muria Kudus University student business, so business actors need to increase their use of IT more effectively and create new ideas in doing business so that consumers feel more focused on certain products.

3. Based on the results of adjusted $r$ square, further research can add independent variables or replace them with other variables such as competitiveness, brand image, and customer satisfaction.

\section{References}

[1] Hasbullah, Fahmi. Analysis of the Effect of Industrial Sector Exports and Foreign Investment in the Industrial Sector on Indonesia's Economic Growth. Essay. Medan: USU's Department of Economic Development, 2009

[2] .Daryanto: Scientific Learning Approach Curriculum 2013. Yogyakarta: Gava Media Publisher,2014

[3] Aprilianti: The influence of entrepreneurial personality, entrepreneurial knowledge, and the environment on the entrepreneurial interest of vocational students. Journal of Vocational Education, Vol 2, Number 3 , November 2015, 2015

[4] Lestari and Wijaya: The Influence of Entrepreneurship Education on Student Entrepreneurial Interest at STIE MDP, STMIK MDP, and STIE MUSI. Scientific Journal of STIE MDP, Vol. 1 No.2: 112-119. Cited 06 20, 2017 from http://eprints.mdp.ac.id/672/, 2016

[5] Bukirom, et al: The Influence of Entrepreneurial Education and Entrepreneurial Motivation on the Entrepreneurship Formation of ISSN Students: 085-1442 accessed on 1 May 2017, 2016

[6] Kotter, John P: Accelerate: Building Strategic Agility for a Faster-Moving World. New York: Free Press, 2014

[7] Sistaningrum. : Product Sales Management. Publisher Kanisius, Yogyakarta, 2012

[8] Tjiptono .: Marketing Management and Consumer Behavior Analysis, Yogyakarta: BPFE, 2012 
[9] Fatoki, Olawale. : The Entrepreneurial Intention of Undergraduate Students in South Africa: The Influences of Entrepreneurship Education and Previous Work Experience. Mediterranean Journal of Social Sciences, 5 (7): 294-299, 2015

[10] Suryana: Creative Economy, New Economy: Changing Ideas, and Creating Opportunities. Jakarta: Four Salemba, 2013

[11] Ofori, D. et al., "Innovation and Knowledge Sharing: A New Competitive Advantage in the Mobile Telecommunication Industry in Ghana", Science Journal of Business and Management, Vol. 3, No. 5, pp. 157-163, 2015

[12] Bachtiar Ibrahim: Plan and Estimated Real of Cost, Bumi Aksara publisher, Jakarta, 2016

[13] Ghobakhloo, Morteza. Arias-Aranda, Daniel, and Benitez-Amado, Jose. : "Adoption of e-commerce applications in SMEs". Industrial Management \& Data Systems Vol. 111 No. 8, 2014 pp. 1238-1269, 2014

[14] Srimindarti, Ceacilia \& Elen Puspitasari,:, Accounting Information System (SIA) performance in terms of SIA user satisfaction and usage, which is influenced by the participation, ability, training and education of SIA users, Scientific Week, SWCU FEB lecturer, Pp. 517-530, 2017

[15] Nursito, S. \& Nugroho, A. J .: Analysis of the Effect of Knowledge Interaction and Self-Efficacy on Entrepreneurial Intention. Journal of Business Tips, 5 (2), p. 149-158, 2015

[16] Wijaya, Ida Bagus \& Purnawati, Ni Ketut .: The Effect of Liquidity and Institutional Ownership on Firm Value Moderated by Dividend Policy. Udayana University Management E-journal, 3 (12): 37683780 (2014).Kasmir. : Pengantar Manajemen Keuangan. Jakarta: Kencana Prenada Media Group, 2015

[17] Baig, A. H. and Gururajan, R. : Preliminary Study to Investigation the Determinants that Effect IS/IT Outsourcing. Journal of Information and Communication Technology Research, 1 (2), pp: 48-54, 2014

[18] Al Eqab, Mahmod., and Dalia Adel. : The Impact of IT Sophistications on the perceived Usefulness Of Accounting Information Characteristics among Jordanian Listed Companies. International Journal of Business and Social Science. 4(3), pp: 143-155, 2016

[19] Purnama, R. A ... Descriptive study regarding the form of impulsive buying among students of the university's faculty of psychology at the age of 18-20 years (unpublished thesis). Faculty of Psychology, Gadjah Mada University. Yogyakarta, 2015

[20] Nelly A.: New Product Quality And Product Development Teams. Journal Of Marketing, 64: 111-123, 2014

[21] Drucker, Peter.F: Management: Duties, Responsibilities and Practices, Jakarta: PT Gramedia, 2012

[22] Dougherty D, Hardy C.: Sustained Product Innovation in Large, Mature Organizations: Overcoming Innovation-to-Organization Problems. Academy of Management Journal 39 (5): 2012.1120-1153, 2012

[23] Wahyono: "Market Orientation and Innovation: Influence on Marketing Performance", Indonesian Journal of Marketing Science, May, 2015

[24] Prakosa, Bagas: The Influence of Market Orientation, Innovation, and Learning Orientation on Company Performance to Achieve Competitive Advantage (Empirical Study of Manufacturing Industry in Semarang). Journal of Management \& Organizational Studies Vol. 2 No. January 1, 2013, 2013

[25] Sugiyono. : Quantitative Research Methods, Qualitative and R \& D. Bandung: Alfabeta.CV, 2014

[26] Ghazali, Imam. : Multivariate Analysis Application with IBM SPSS 23 Program (8th Edition). VIII printing. Semarang: Diponegoro University Publishing Agency, 2016

[27] Taprial, Varinder \& Kanwar, Priya: Understanding Social Media. Ventus Publishing. ISBN [978-877681-992-7], 2017

[28] Hayden J. Introduction to health behavior theory [Internet]. Jones \& Bartlett Learning, 2014

[29] Ardiyani NA, Nugrahaeni R.: Analysis of the influence of the work environment, quality, leadership, and work motivation on employee performance (studies at PT PLN Persero Central Java Distribution Office and D.I.Yogyakarta). Diponegoro Journal of Management 6 (4): 1-10, 2017

[30] Tamamudin .: "Analysis of the Effect of Brand Recognition, Perceptions of Quality, Consumer Expectations and Product Innovation on Purchasing Decisions and Their Impact on Consumer Loyalty". Research Journal Vol. 9, No. 2, November 2014. Pg. 283-300, 2014

[31] Azwar, S.: Reliability and validity. Yogyakarta: Student Library, 2015 